\title{
Does One Size Fit All?
}

Kemna MJ, Cohen Tervaert JW. Does one size fit all? J Rheumatol 2013;40:1781-4. In reference 14, the order of authors' names should be: Grayson PC, Cuthbertson D, Carette S, Hoffman G, Khalidi N, Koening CL, et al. We regret the error.

doi:10.3899/jrheum.130805.C1 